\title{
Review \\ Skin-Resident Memory T Cells: Pathogenesis and Implication for the Treatment of Psoriasis
}

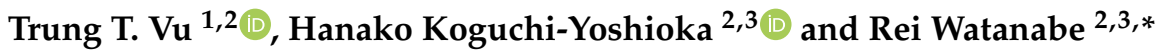 \\ 1 Department of Cutaneous Immunology, Immunology Frontier Research Center, Osaka University, \\ Osaka 565-0871, Japan; trungvu0406@derma.med.osaka-u.ac.jp \\ 2 Department of Dermatology, Course of Integrated Medicine, Graduate School of Medicine/Faculty of \\ Medicine, Osaka University, Osaka 565-0871, Japan; stain_way@yahoo.co.jp \\ 3 Department of Integrative Medicine for Allergic and Immunological Diseases, Course of Integrated Medicine, \\ Graduate School of Medicine/Faculty of Medicine, Osaka University, Osaka 565-0871, Japan \\ * Correspondence: rwatanabe@derma.med.osaka-u.ac.jp
}

Citation: Vu, T.T.; Koguchi-Yoshioka H.; Watanabe, R. Skin-Resident Memory T Cells: Pathogenesis and Implication for the Treatment of Psoriasis. J. Clin. Med. 2021, 10, 3822. https://doi.org/10.3390/jcm10173822

Academic Editor: Mayumi Komine

Received: 22 July 2021

Accepted: 21 August 2021

Published: 26 August 2021

Publisher's Note: MDPI stays neutral with regard to jurisdictional claims in published maps and institutional affiliations.

Copyright: (c) 2021 by the authors. Licensee MDPI, Basel, Switzerland. This article is an open access article distributed under the terms and conditions of the Creative Commons Attribution (CC BY) license (https:// creativecommons.org/licenses/by/ $4.0 /)$.

\begin{abstract}
Tissue-resident memory $\mathrm{T}$ cells $\left(\mathrm{T}_{\mathrm{RM}}\right)$ stay in the peripheral tissues for long periods of time, do not recirculate, and provide the first line of adaptive immune response in the residing tissues. Although $\mathrm{T}_{\mathrm{RM}}$ originate from circulating $\mathrm{T}$ cells, $\mathrm{T}_{\mathrm{RM}}$ are physiologically distinct from circulating $\mathrm{T}$ cells with the expression of tissue-residency markers, such as CD69 and CD103, and the characteristic profile of transcription factors. Besides defense against pathogens, the functional skew of skin $\mathrm{T}_{\mathrm{RM}}$ is indicated in chronic skin inflammatory diseases. In psoriasis, IL-17A-producing $\mathrm{CD}^{+} \mathrm{T}_{\mathrm{RM}}$ are regarded as one of the pathogenic populations in skin. Although no licensed drugs that directly and specifically inhibit the activity of skin $\mathrm{T}_{\mathrm{RM}}$ are available to date, psoriatic skin $\mathrm{T}_{\mathrm{RM}}$ are affected in the current treatments of psoriasis. Targeting skin $\mathrm{T}_{\mathrm{RM}}$ or using $\mathrm{T}_{\mathrm{RM}}$ as a potential index for disease severity can be an attractive strategy in psoriasis.
\end{abstract}

Keywords: skin-resident memory T cells; human; psoriasis; cytokines; autoantigens; treatment

\section{Introduction}

Once the immune system encounters antigens, memory $\mathrm{T}$ cells are generated from the naïve $\mathrm{T}$ cells and facilitate a prompt response to the re-exposure of the same antigens. Two populations of memory $\mathrm{T}$ cells have been defined from human blood circulation: effector memory $\mathrm{T}$ cells $\left(\mathrm{T}_{\mathrm{EM}}\right)$ and central memory $\mathrm{T}$ cells $\left(\mathrm{T}_{\mathrm{CM}}\right)$ [1]. $\mathrm{T}_{\mathrm{EM}}$ are also dominant in peripheral non-lymphoid tissues and $\mathrm{T}_{\mathrm{CM}}$ have an affinity for secondary lymphoid organs [2,3]. Furthermore, research on murine infectious disease models has revealed that a subpopulation of $\mathrm{T}_{\mathrm{EM}}$ found in peripheral tissues remain in the same tissues for long periods without recirculation after cure of infection [4-6]. These findings led to the establishment of the new population of memory $T$ cells, tissue-resident memory $T$ cells $\left(T_{R M}\right)$.

$\mathrm{T}_{\mathrm{RM}}$ are superior to their circulating memory counterparts in their ability to provide the local adaptive cellular defense [7-11]. They can respond to the local antigen re-exposure without the recruitment of circulating $T$ cells to the tissue [12]. In addition, recent studies suggest $T_{\mathrm{RM}}$ also contribute to systemic immune responses upon subsequent exposure to specific antigens by proliferating and baring circulating populations, such as $\mathrm{T}_{\mathrm{CM}}$ and $\mathrm{T}_{\mathrm{EM}}[13,14]$.

The existence and functional activities of $\mathrm{T}_{\mathrm{RM}}$ were initially investigated in barrier tissues, such as the gut $[6,15]$, skin $[4,5,12,16,17]$, respiratory tract $[18,19]$, and reproductive tract $[20,21]$, in the context of local defense against pathogens in infectious diseases. However, their roles are now recognized in various conditions, including cancer immunity, tissue-specific autoimmune diseases, and chronic inflammatory diseases both in barrier and non-barrier tissues [22].

Skin $\mathrm{T}_{\mathrm{RM}}$ are among the intensively studied $\mathrm{T}_{\mathrm{RM}}$ populations not only in murine models but also in humans. The human skin contains an estimate of 20 billion $\mathrm{T}$ cells, 
doubling those in the circulation [23], and over half of these $\mathrm{T}$ cells show the $\mathrm{T}_{\mathrm{RM}}$ phenotype [24]. Besides infectious diseases, the involvement of skin $T_{R M}$ has been reported in allergic contact hypersensitivity [25]; fixed drug eruption [26]; cutaneous malignancies, including malignant melanoma [27,28] and cutaneous T-cell lymphoma [24,29]; and chronic inflammatory diseases, such as vitiligo, alopecia, and psoriasis [30,31].

In this review, we provide an overview of the general characteristics of $\mathrm{T}_{\mathrm{RM}}$. Then, narrowing our focus to skin $T_{R M}$ in humans, we summarize the involvement of skin $T_{R M}$ in cutaneous disorders, especially psoriasis. We also mention the possibility of engaging $\mathrm{T}_{\mathrm{RM}}$ as a disease index and treatment target in psoriasis. Since $\mathrm{CD} 8^{+} \mathrm{T}_{\mathrm{RM}}$ are the bestcharacterized population, we focus on $\mathrm{CD}^{+} \mathrm{T}_{\mathrm{RM}}$ and describe this population as $\mathrm{T}_{\mathrm{RM}}$ in this review unless otherwise mentioned.

\section{The Characteristics of $T_{R M}$}

$\mathrm{T}$ cells in the neonatal murine skin are predominant with dendritic epidermal $\mathrm{T}$ cells (DETCS) with restricted antigenic specificity [32], and neonatal human skin holds only a few $\mathrm{T}$ cells [24]. Thus, $\mathrm{T}_{\mathrm{RM}}$ are assumed to develop from circulating $\mathrm{T}$ cells according to repeated antigen exposure. In the local inflammation caused by specific antigens, the robustly expanded effector $\mathrm{T}$ cells emerge in the circulation and the affected tissues, and both $\mathrm{T}_{\mathrm{CM}}$ and $\mathrm{T}_{\mathrm{RM}}$ are assumed to arise from a part of these effector $\mathrm{T}$ cells $[25,33]$.

The general characteristics of $\mathrm{T}_{\mathrm{RM}}$ across the tissues include the loss of migration and the gain of retention. The development and maintenance of these characteristics in $T_{\mathrm{RM}}$ are driven by complex factors, such as cytokine and chemokine receptors, the other cell-surface molecules being responsible for tissue homing and retention, and transcription factors (Figure 1).

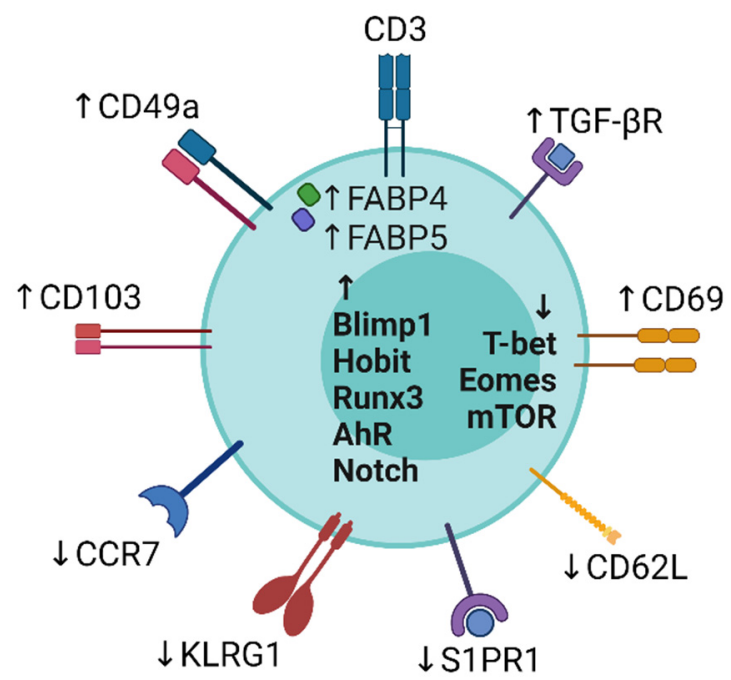

Figure 1. A. Surface markers, intracellular molecules, and transcription factors of $\mathrm{T}_{\mathrm{RM}}$. The expression levels of these molecules on $\mathrm{T}_{\mathrm{RM}}$ are shown by upward arrows (increased expressions) and downward arrows (decreased expressions). Created with BioRender.com (accessed on 21 August 2021).

\subsection{Cell Surface Molecules}

While homing molecules including chemokine receptors are diverse depending on the target peripheral tissues, the molecules related to tissue retention seem to be shared among various tissues. In general, $\mathrm{T}_{\mathrm{RM}}$ lack the expression of the secondary lymphoid homing molecules CC-chemokine receptor 7 (CCR7) and L-selectin, which are expressed on $\mathrm{T}_{\mathrm{CM}}$ and naïve T cells [1]. The tissue retention molecules CD69 and CD103 ( $\alpha \mathrm{E}$ integrin) are widely recognized as the markers for $\mathrm{T}_{\mathrm{RM}}$. $\mathrm{CD} 103$ is a ligand of E-cadherin that is expressed on epithelial cells [34], and CD69 interferes with sphingosine-1-phosphate (S1P) receptor-1, which allows the cells to exit from peripheral tissues by sensing the density of S1P [35]. CD69 also reportedly regulates the uptake of L-tryptophan and the intracellular quantity 
of L-tryptophan-derived activator of the aryl hydrocarbon receptor (AhR) [36], which is reportedly involved in the persistence of $\mathrm{T}_{\mathrm{RM}}$ [32]. These functions would explain at least partially the importance of these molecules in tissue retention. However, their expression varies, possibly depending on the tissues and the causes of $\mathrm{T}_{\mathrm{RM}}$ development. $\mathrm{T}_{\mathrm{RM}}$ lacking CD103 expression have been described in some peripheral tissues and secondary lymphoid organs $[37,38]$ and $\mathrm{CD}_{103^{+}} \mathrm{T}_{\mathrm{RM}}$ can be found in the dermis and adult central nervous system where E-cadherin is absent, implying that binding to E-cadherin is not required for the persistence of $\mathrm{T}_{\mathrm{RM}}$ in peripheral tissues [24,39]. Although CD69 is expressed on the majority of $T_{R M}$ in various peripheral tissues, $T_{R M}$ negative for CD69 expression are also noted [33]. We thus have to take into account that these two molecules are not able to cover $\mathrm{T}_{\mathrm{RM}}$ universally.

\subsection{Transcription Factors}

Transcriptional regulation is also presumably common among $\mathrm{T}_{\mathrm{RM}}$ in various tissues. For instance, the expression of $A h R$ is increased in skin $T_{R M}$ as compared with naïve $T$ cells and splenic $\mathrm{T}$ cells, possibly favoring the maintenance of skin $\mathrm{T}_{\mathrm{RM}}$ [32]. Rapamycin inhibits the formation of $\mathrm{T}_{\mathrm{RM}}$ in the intestinal and vaginal mucosa, highlighting a positive link of mammalian target of rapamycin and the downstream transcription factors with the formation of $T_{R M}$ [40]. The maintenance of lung $T_{R M}$ may be related to Notch signaling, including the upregulation of the downstream transcription factor RBPJ [41]. The augmented uptake of exogenous lipids accompanied by the upregulation of fatty acid binding proteins (FABPs) 4 and 5 is one of the characteristic processes involved in the generation and maintenance of skin $T_{R M}$ [42]. Hypoxia-inducible factor- $1 \alpha$, which is a transcription factor in the downstream of FABP5 signaling, reportedly promotes the residency and anti-tumor function of tumor-infiltrating $\mathrm{T}$ cells in the murine malignancy model [43]. The downregulation of T-box transcription factors T-bet and EOMES [44] and the upregulation of Blimp-1, Hobit [45], and Runx3 [46,47] have also been reported to be involved in the differentiation and/or maintenance of $\mathrm{T}_{\mathrm{RM}}$.

\subsection{Skin-Homing Molecules}

In addition to the shared characteristics of various $\mathrm{T}_{\mathrm{RM}}$, skin $\mathrm{T}_{\mathrm{RM}}$ are shown to have their own homing molecules. As one of skin's homing molecules, cutaneous lymphocyteassociated antigen (CLA) binds to E-selectin and P-selectin and allows the cells to migrate into skin [23]. The chemokine receptors CCR4, CCR8, CCR10, CXCR3, and CXCR6 are also regarded as important skin-homing and/or retention molecules for at least some skin $\mathrm{T}$ cells [16,48-52].

\subsection{Fate Decision of $T_{R M}$}

How the fate of $T_{R M}$ differentiation is decided remains an unsolved question. $T_{R M}$ reportedly derive from circulating $\mathrm{T}$ cells lacking high expression of the killer cell lectin-like receptor subfamily $\mathrm{G}$ member 1 (KLRG1), which is regarded as a terminal differentiation marker $[16,47]$. Another report demonstrates that the effector $\mathrm{T}$ cells with enriched expression of $\mathrm{T}_{\mathrm{RM}}$-associated genes, such as Itgae (CD103), Itga1 (CD49a), Cd101, Ahr, and Fabp5, already exist as memory precursor cells and preferentially differentiate into $\mathrm{T}_{\mathrm{RM}}$ [53], suggesting that the fate of $\mathrm{T}_{\mathrm{RM}}$ is at least partially decided in the early stage of adoptive immune memory formation. On the other hand, the time-course single-cell RNA-sequencing analysis in a murine model with lymphocytic-choriomeningitis-virus infection revealed that the transcriptional characteristics of $\mathrm{T}_{\mathrm{RM}}$ can be detected from gut-infiltrating $\mathrm{T}$ cells at the earliest 4 days after infection, and the characteristics are distinct from those found in splenic $\mathrm{T}$ cells [54], implying that the $\mathrm{T}_{\mathrm{RM}}$ differentiation program is initiated after the cells enter the specific peripheral tissues. Further elucidation of the $T_{R M}$ differentiation mechanism will require further research. 


\section{Human Skin $T_{R M}$}

In general, human $\mathrm{T}_{\mathrm{RM}}$ and murine $\mathrm{T}_{\mathrm{RM}}$ share core transcriptional, phenotypic, and functional profiles, including the almost global expression of CD69 and dominant CD103 expression in CD8 fractions [45,55-57]. In patients with cutaneous T-cell lymphoma (CTCL), the treatment with alemtuzumab, which depletes circulating $T$ cells and spares the $T_{R M}$, does not result in serious infection [58], implying the role of skin $\mathrm{T}_{\mathrm{RM}}$ in protective immunity. The $\mathrm{T}_{\mathrm{RM}}$ phenotype of the malignant cells in CTCL is related to the clinical manifestation of well-demarcated lesions, suggesting that the sessile property of $\mathrm{T}_{\mathrm{RM}}$ also exists in humans [24]. In vitro experiments suggest skin $\mathrm{T}_{\mathrm{RM}}$ maintain the production of IL-17A and IFN- $\gamma$ in reaction with pathogen challenges through aging [59]. Using transcriptomic and functional data, human $\mathrm{T}_{\mathrm{RM}}$ are found to abolish their senescent phenotype and survive for over 10 years in specific circumstances [46], replicating the longevity of $\mathrm{T}_{\mathrm{RM}}$ in humans.

However, $\mathrm{T}_{\mathrm{RM}}$ in humans are presumably more diverse and widely distributed. For instance, $\mathrm{CD}^{+} \mathrm{T}_{\mathrm{RM}}$ are found in both the epidermis and dermis in humans, although murine skin $\mathrm{CD}^{+} \mathrm{T}_{\mathrm{RM}}$ are predominantly found in dermis $[17,24,60,61] . \mathrm{T}_{\mathrm{RM}}$ are also found in secondary lymphoid organs, such as the spleen, lymph nodes, and tonsils in humans $[55,56]$.

The factors that may cause the difference between human skin $T_{R M}$ properties and those observed in laboratory mice may include the following: (1) the thick epidermis with abundant niche for $\mathrm{T}_{\mathrm{RM}}$ [24,62]; (2) the low density of hair follicles that express cytokines important for $\mathrm{T}_{\mathrm{RM}}$ migration and survival, including IL-7 and IL-15 [63,64]; (3) the frequent exposure to foreign antigens; (4) the small population of $\gamma \delta \mathrm{T}$ cells with the lack of DETC in the human epidermis [65] (however, we do not know whether the recently identified $\alpha \beta \gamma \delta$ T cell population in fetal skin can replace DETC) [66]. The longer survival period of human $\mathrm{T}_{\mathrm{RM}}$ compared to murine life span [46] may also cause difficulty in adapting the findings in murine models to human biology.

The involvement of skin $\mathrm{T}_{\mathrm{RM}}$ is highlighted in chronic inflammatory disorders and cutaneous malignancies. In the lesional skin of alopecia areata, $\mathrm{T}_{\mathrm{RM}}$ with the ability to produce granzyme $\mathrm{B}$ are dominant and related to disease prognosis, implying their involvement in the pathogenesis [67]. Intraepidermal IFN- $\gamma$-producing $\mathrm{T}_{\mathrm{RM}}$ are enriched in the cured sites of fixed drug eruption [26], suggesting the contribution of this fraction to the reproducible property. In patients with atopic dermatitis, cutaneous $\mathrm{T}_{\mathrm{RM}}$ with the production of IL-4 and IL-13 are also indicated to be involved in the disease pathogenesis [68]. Dermal $T_{R M}$ are increased with the production potential of perforin, granzyme $\mathrm{B}$, and IFN- $\gamma$ in vitiligo $[30,69]$, which are presumably specific for melanocyte antigens. In malignant melanoma, skin $T_{R M}$ provide protection against tumor regrowth and are involved in vitiligo formation, suggestive of their specific reactivity against melanoma antigens [70]. Better understanding of cutaneous $\mathrm{T}_{\mathrm{RM}}$ will pave the way for novel management and treatment of skin diseases.

The methodologies for evaluating skin $\mathrm{T}_{\mathrm{RM}}$ are summarized in Table 1 . In the translational research field, one of the most popular methods for analyzing $\mathrm{T}_{\mathrm{RM}}$ is fluorescenceactivated cell sorting (FACS) analysis. However, conducting this method from biopsied skin specimens is not practical in the daily clinical settings considering the burden for both patients and clinicians. Immunohistochemistry (IHC) and/or immunofluorescence (IF) for $\mathrm{T}_{\mathrm{RM}}$-related molecules, such as CD3, CD8, CD69, and CD103, on the residual biopsy specimens carried out for diagnosis is probably more feasible to date. To establish noninvasive methods for predicting the activities of skin $\mathrm{T}_{\mathrm{RM}}$, such as analyzing tape-stripped or surface-swabbed samples, will require further research.

\section{Skin $T_{R M}$ in the Pathogenesis of Psoriasis}

Psoriasis, hereafter referred to as plaque psoriasis, is an immune-mediated chronic inflammatory skin disorder characterized by well-demarcated persistent scaly indurated erythematous plaques. The contributions of environment [71], hereditary predisposition [72], 
and autoantigens [73] are implied to be involved in disease development. Circulating T cells were previously regarded as responsible for the lesion formation in psoriasis. However, the inhibition of E-selectin, which is required for T-cell migration from the blood stream to skin, was noted to be ineffective [74]. Another blocking strategy of T-cell migration by the biologics targeting CD11a also did not show dramatic efficacy [75]. However, in a humanized murine model where psoriatic nonlesional skin specimens are grafted to immunodeficient mice [76], the healthy-appearing nonlesional skin grafts spontaneously develop psoriatic disease, suggesting that the cells residing in the nonlesional skin are sufficient for the development of psoriatic disease. These results have led to the theory that $\mathrm{T}_{\mathrm{RM}}$ may play a crucial role in the pathogenesis of psoriasis.

The fate of skin $\mathrm{T}_{\mathrm{RM}}$ is affected by the skin microenvironment, and in psoriasis, this is also the case. Several skin-constituting factors have been reported to support the development and persistence of IL-17A-producing $\mathrm{T}_{\mathrm{RM}}$ in psoriasis. Keratinocytes in disease-naïve sites of psoriasis upregulate the expression of chemokines, such as CCL20 upon stimulation by skin commensal fungi [77]. Since CCL20 is a ligand for CCR6, which is a signature molecule of IL-17A-producing T cells, the activated keratinocytes in the disease-naïve sites of psoriasis are to recruit IL-17A-producing T cells to the disease-naïve sites, leading to the accumulation of IL-17A-producing $\mathrm{T}_{\mathrm{RM}}$ [77]. In turn, IL-17A from $\mathrm{T}_{\mathrm{RM}}$ stimulates keratinocytes to express CCL20, further accelerating the recruitment of $\mathrm{CCR}^{+}$cells [78]. In the resolved skin, the continuous production of IL-23 and IL-15 from Langerhans cells presumably support the maintenance of IL-17A-producing $\mathrm{T}_{\mathrm{RM}}$ in the epidermis [79]. The reduced repertoire of IL-17A-producing T cells in the resolved skin, which has been observed in different psoriatic patients, implies the existence of common antigens that drive the accumulation of psoriatic $T_{R M}$ [80]. Several potential autoantigens have been reported in psoriasis (Figure 2). For example, cationic antimicrobial peptide LL-37 produced by various cells including keratinocytes binds self-DNA and triggers the activation of plasmacytoid dendritic cells (pDC) and TNF/iNOS-producing dendritic cells (TIP-DC) [81,82]. A disintegrin-like and metalloprotease domain containing thrombospondin type 1 motif-like 5 (ADAMTSL5) in complex with HLA-C*06:02 on the surface of melanocytes confers epidermal CD ${ }^{+}$T-cell response [83]. Neo-lipid antigens generated by phospholipase A2 group 4D (PLA2G4D) from mast cells and keratinocytes trigger the CD1a-reactive T cells to produce IL-17A and IL-22 [84]. Keratin 17, a human epidermal keratin that shares a sequential homology with streptococcal $\mathrm{M}$ protein, is recognized by HLA-Cw* ${ }^{*} 0602$-restricted IFN- $\gamma$-producing $\mathrm{CD}^{+} \mathrm{T}$ cells $[85,86]$. Taken together, these results suggest the synchronizing roles of the skin microenvironment in the development and persistence of pathogenic cutaneous $\mathrm{T}_{\mathrm{RM}}$.

In the lesional skin of patients with psoriasis, $\mathrm{T}_{\mathrm{RM}}$ consist of both $\mathrm{CD} 4$ and $\mathrm{CD} 8$ fractions, which synchronize the elevated immune response by the increased expression of inflammatory cytokines, such as IL-17A, IL-22, and IFN- $\gamma[62,80,87,88]$. While IL-17Aproducing $\mathrm{CD}^{+} \mathrm{T}_{\mathrm{RM}}$ also exist in healthy skin, the enrichment of $\mathrm{CD} 8^{+} \mathrm{T}_{\mathrm{RM}}$ producing IL-17A in the epidermis is one of the characteristics of psoriasis [87,88]. In disease-naïve skin that has never experienced disease formation, IL-17A production is augmented by $\mathrm{T}_{\mathrm{RM}}$ [77], and the increase in IL-17A-producing CD8 ${ }^{+} \mathrm{T}_{\mathrm{RM}}$ at the dispense of IFN- $\gamma$-producing $\mathrm{T}_{\mathrm{RM}}$ occurs according to disease duration [88].

IFN- $\gamma$-producing $\mathrm{T}_{\mathrm{RM}}$ are also dominant in the epidermis and express the complex of CD49a-CD29, also known as very late antigen 1 (VLA-1) or $\alpha 1 \beta 1$ integrin [76]. CD49a ${ }^{+}$ $\mathrm{T}_{\mathrm{RM}}$ are involved in the pathogenesis of psoriasis. The number of epidermal $\mathrm{CD} 8^{+} \mathrm{CD} 49 \mathrm{a}^{+}$ $\mathrm{T}_{\mathrm{RM}}$ correlates with the severity of the disease [89], and an experimental blockade of CD49a in mice transplanted with psoriatic skin reduces the disease formation [76]. However, since the blockade of whole $\mathrm{CD} 8^{+} \mathrm{T}$ cells almost completely prevents disease development in the similar psoriatic skin-engrafted murine model [90], CD49a ${ }^{+} \mathrm{T}_{\mathrm{RM}}$ with IFN- $\gamma$ production are not likely the key population for disease development, while the $\mathrm{CD} 8^{+} \mathrm{T}$ cell population likely includes a critical fraction for disease pathogenesis. In fact, $C D 8^{+} \mathrm{T}_{\mathrm{RM}}$ without the expression of CD49a are defined as an IL-17A-producing $\mathrm{T}_{\mathrm{RM}}$ subset [30]. 


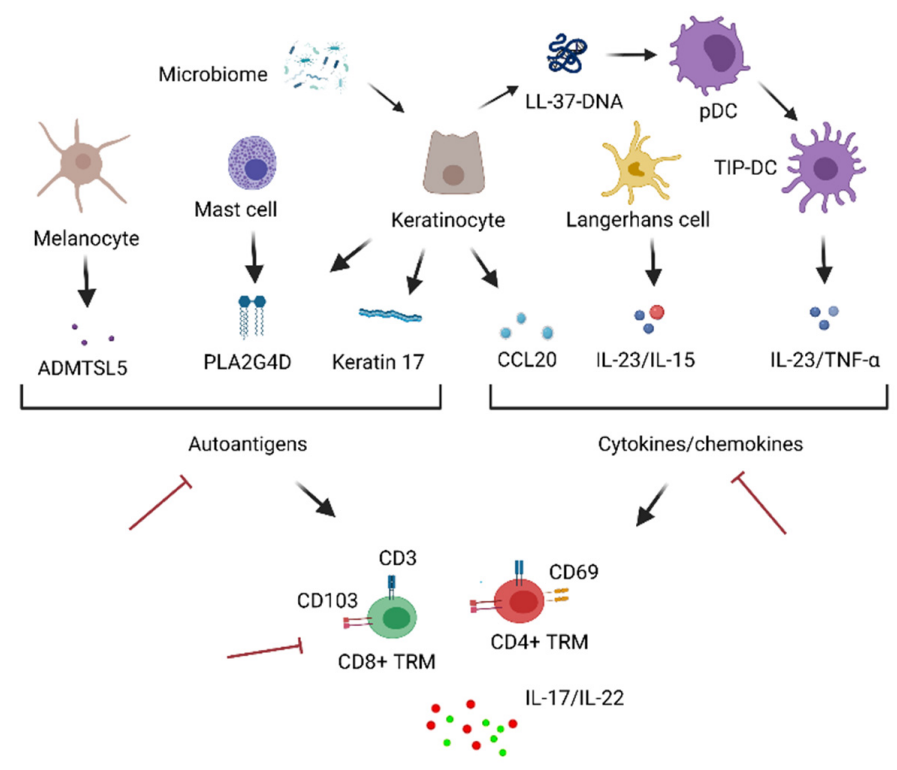

Figure 2. Development of $\mathrm{T}_{\mathrm{RM}}$ in psoriasis. $\mathrm{T}_{\mathrm{RM}}$ are activated by either autoantigens or cytokines/chemokines. Autoantigens include ADMTSL5 on the surface of melanocytes, PLAG4D from mast cells and keratinocytes, and keratin 17 from keratinocytes. Antimicrobial peptide LL-37, also from keratinocytes, binds to self-DNA to activate PDC and TIP-DC, leading to the production of IL-23/TNF- $\alpha$. IL-23/15 from Langerhans cells and CCL20 from keratinocytes also activate $\mathrm{T}_{\mathrm{RM}}$. These stimulated $\mathrm{T}_{\mathrm{RM}}$ produce proinflammatory cytokines, such as IL-17A and IL-22, the hallmarks of psoriasis. The development of pathogenic $\mathrm{T}_{\mathrm{RM}}$ can be inhibited by stopping pathways related to $\mathrm{T}_{\mathrm{RM}}$ activation or directly inhibiting the activity of $\mathrm{T}_{\mathrm{RM}}$ (red inhibition icon). Created with BioRender.com (assessed on 21 August 2021).

Successful treatment with an IL-17A-targeting biologics results in a decreased number of IL-17A-producing $\mathrm{T}_{\mathrm{RM}}$ in resolved skin, but the frequency of these cells is not altered within the remaining T cells [91]. Another study on residual psoriasis after the use of biologics revealed a decrease in keratinocyte proliferation. However, the percentage of IL-17A-producing $\mathrm{CD}_{103^{+}} \mathrm{T}_{\mathrm{RM}}$ was not significantly reduced after the treatments [92]. Similarly, a new normal in the persistence of IL-17A-producing $\mathrm{T}_{\mathrm{RM}}$ with CCR6 and IL-23R expression in the resolved skin has been established [62,80]. IL-17A-producing $\mathrm{CD}^{+} \mathrm{T}_{\mathrm{RM}}$ and IL-22-producing $\mathrm{CD}^{+} \mathrm{T}_{\mathrm{RM}}$ remain in the psoriatic epidermis for as long as six years after starting the successful TNF- $\alpha$-targeting treatment [62]. Taken together, these findings highlight the essential standing point of IL-17A-producing $\mathrm{T}_{\mathrm{RM}}$ as one of the pathogenic populations of skin $\mathrm{T}_{\mathrm{RM}}$ in psoriasis.

\section{Targeting Skin $T_{R M}$ in the Management of Psoriasis}

Regardless of the persistence of this population by various treatments in psoriasis, many of the current and upcoming therapeutics in clinical practice presumably exert an indirect influence on cutaneous IL-17A-producing $\mathrm{T}_{\mathrm{RM}}$. Since the remission period after successful treatments inversely correlates with the relative IL-17 signaling of the resolved skin compared to IL-10 and IFN- $\gamma$ signaling [93], the relative reduction, if not elimination, of IL-17A-producing $\mathrm{T}_{\mathrm{RM}}$ may be of help in controlling psoriatic disease activity.

Biologics targeting the IL-17 pathway reportedly reduce IL-17 signaling and the amount of T cells in the lesion [94]. Furthermore, the biologics targeting IL-23 decrease this fraction from the lesion more strongly compared to those targeting IL-17A [95]. Ultraviolet irradiation leads to the diminishment of IL-17A-producing T cells in skin [96], and this T-cell fraction includes $\mathrm{T}_{\mathrm{RM}}$. Topical vitamin $\mathrm{D}$ analogues and corticosteroids reportedly reduce the lesional IL-17A-producing $\mathrm{T}_{\mathrm{RM}}$, possibly including pathogenic $\mathrm{T}_{\mathrm{RM}}[97,98]$. Retinoic acid prevents Th17 differentiation and possibly promotes the properties of regulatory $\mathrm{T}$ cells $[99,100]$. As the oral phosphodiesterase 4 inhibitor (PDE4i) diminishes the pro- 
inflammatory cytokine production from circulating $\mathrm{T}$ cells [101], the function of both topical and systemic PDE4i could be revisited from the perspective of skin $T_{R M}$. An AhR agonist modulates the Th17 property of T cells, and the efficacy of its topical form possibly affects IL-17A-producing $\mathrm{T}$ cells in skin, including $\mathrm{T}_{\mathrm{RM}}$ [102].

Proof-of-concept approaches that directly and exclusively target pathogenic populations of $\mathrm{T}_{\mathrm{RM}}$ should be subjected to further studies. The candidate strategies might include the inhibition of the pathways involved in IL-15 signaling to perturb the survival of pathogenic $\mathrm{T}_{\mathrm{RM}}$ and the blockade of the pathways processing fatty acids to suppress the lipid metabolism of pathogenic $\mathrm{T}_{\mathrm{RM}}$. Targeting the transcription factors specified for differentiation and maintenance of pathogenic $T_{R M}$ is also an attractive strategy. However, although the risk of targeting these populations of $T_{R M}$ is unknown, it may cause the loss of local immune memory against pathogens in the skin. Since the characteristic cell surface molecules and transcription factors found in $\mathrm{T}_{\mathrm{RM}}$ properties can be overlapped with the sessile properties of other cell types, such as innate lymphoid cells and B cells [103,104], the strategies targeting $\mathrm{T}_{\mathrm{RM}}$ might also affect the other tissue-sessile immunity. Specific treatment targets for psoriatic dysfunctional $\mathrm{T}_{\mathrm{RM}}$, excluding the other $\mathrm{T}_{\mathrm{RM}}$ and skin-resident immune cells, would be ideal.

\section{Conclusions}

Extensive studies with rigorous methodologies have broadened our knowledge on $\mathrm{T}_{\mathrm{RM}}$ in general and those residing in the skin in particular (Table 1). The involvement of skin $\mathrm{T}_{\mathrm{RM}}$ in the pathogenesis of skin diseases is also being elucidated. Several key points are highlighted below:

- $\mathrm{T}_{\mathrm{RM}}$ originate from circulating $\mathrm{T}$ cells, do not recirculate, and provide the first line of adaptive cellular defense in the residing tissues.

- The functional skew of skin $\mathrm{T}_{\mathrm{RM}}$ is indicated in chronic skin inflammatory diseases.

- In psoriasis, IL-17-A-producing $\mathrm{CD}^{+} \mathrm{T}_{\mathrm{RM}}$ may be among the pathogenic populations in the skin.

- Pathogenic populations of skin $\mathrm{T}_{\mathrm{RM}}$ can be targeted in the current and future treatments of psoriasis. Skin $\mathrm{T}_{\mathrm{RM}}$ can also serve as a potential index of the disease.

Further studies on $\mathrm{T}_{\mathrm{RM}}$ will advance the management of not only psoriasis but other diseases in which this subset of $\mathrm{T}$ cells plays a role.

Table 1. Several major findings related to methodologies used in research on humans.

\begin{tabular}{|c|c|c|}
\hline Key Findings & Major Methodologies & \\
\hline A role of skin $T_{R M}$ in protective immunity in humans & FACS & [58] \\
\hline $\begin{array}{l}\text { Skin } T_{R M} \text { with the potential of producing cytokines are } \\
\text { infiltrated in the lesion of patients with GVHD }\end{array}$ & FC, single-cell TCR sequencing, and IF & [46] \\
\hline $\begin{array}{l}\text { Cells residing in nonlesional skin are sufficient, and the } \\
\text { recruitment of circulating cells is not necessary for the } \\
\text { development of psoriatic disease }\end{array}$ & $\begin{array}{l}\text { Transplantation, FC, quantitative } \\
\text { RT-PCR, and IHC }\end{array}$ & [76] \\
\hline $\begin{array}{l}\mathrm{CD} 8^{+} \mathrm{T}_{\mathrm{RM}} \text { producing IL-17A in the epidermis is one of the } \\
\text { characteristics in psoriasis }\end{array}$ & FC and IHC & [87] \\
\hline $\begin{array}{l}\text { The increase in IL-17A-producing } \mathrm{CD} 8^{+} \mathrm{T}_{\mathrm{RM}} \text { during the } \\
\text { distribution of IFN- } \gamma \text {-producing } \mathrm{T}_{\mathrm{RM}} \text { occurs according to } \\
\text { psoriasis duration }\end{array}$ & FC and IF & [88] \\
\hline $\begin{array}{l}\text { The successful treatment with IL-17A-targeting biologics } \\
\text { results in a decreased number of IL-17A-producing CD } 8^{+} \\
\mathrm{T}_{\mathrm{RM}} \text { in resolved psoriatic skin, but the frequency of these } \\
\text { cells is not altered }\end{array}$ & FC, IHC, and IF & [91] \\
\hline $\begin{array}{l}\text { IL-17A-producing CD8 }{ }^{+} \mathrm{T}_{\mathrm{RM}} \text { and IL-22-producing CD4 } \\
\mathrm{T}_{\mathrm{RM}} \\
\text { years after in the psoriatic epidermis for as long as six } \\
\text { treatment }\end{array}$ & FC, quantitative RT-PCR, and IF & [62] \\
\hline
\end{tabular}


Author Contributions: Conceptalization, T.T.V., H.K.-Y. and R.W.; writing-original draft preparation, T.T.V.; writing-review and editing T.T.V., H.K.-Y. and R.W.; visualization, T.T.V., H.K.-Y. and R.W.; supervision, R.W. All authors have read and agreed to the published version of the manuscript.

Funding: T.T.V. is funded by Kishimoto Foundation Fellowship.

Conflicts of Interest: R.W. received lecture fees from the companies Abbvie, Eli Lilly, Janssen Pharmaceuticals, Kyowa Kirin, Maruho, and Novartis, and a research grant from the companies Maruho and Janssen Pharmaceuticals. The funders have no role in the writing or in the decision to publish this manuscript.

\section{References}

1. Sallusto, F.; Lenig, D.; Förster, R.; Lipp, M.; Lanzavecchia, A. Two subsets of memory T lymphocytes with distinct homing potentials and effector functions. Nature 1999, 401, 708-712. [CrossRef]

2. Masopust, D.; Vezys, V.; Marzo, A.L.; Lefrançois, L. Preferential Localization of Effector Memory Cells in Nonlymphoid Tissue. Science 2001, 291, 2413-2417. [CrossRef] [PubMed]

3. Reinhardt, R.L.; Khoruts, A.; Merica, R.; Zell, T.; Jenkins, M.K. Visualizing the generation of memory CD4 T cells in the whole body. Nature 2001, 410, 101-105. [CrossRef] [PubMed]

4. Gebhardt, T.; Wakim, L.M.; Eidsmo, L.; Reading, P.C.; Heath, W.R.; Carbone, F.R. Memory T cells in nonlymphoid tissue that provide enhanced local immunity during infection with herpes simplex virus. Nat. Immunol. 2009, 10, 524-530. [CrossRef]

5. Wakim, L.M.; Waithman, J.; van Rooijen, N.; Heath, W.R.; Carbone, F.R. Dendritic Cell-Induced Memory T Cell Activation in Nonlymphoid Tissues. Science 2008, 319, 198-202. [CrossRef]

6. Masopust, D.; Choo, D.; Vezys, V.; Wherry, E.J.; Duraiswamy, J.; Akondy, R.; Wang, J.; Casey, K.A.; Barber, D.L.; Kawamura, K.S.; et al. Dynamic T cell migration program provides resident memory within intestinal epithelium. J. Exp. Med. 2010, 207, 553-564. [CrossRef] [PubMed]

7. Khalil, S.; Bardawil, T.; Kurban, M.; Abbas, O. Tissue-resident memory T cells in the skin. Inflamm. Res. 2020, 69, 245-254. [CrossRef]

8. Watanabe, R. Protective and pathogenic roles of resident memory T cells in human skin disorders. J. Dermatol. Sci. 2019, 95, 2-7. [CrossRef]

9. Schenkel, J.M.; Masopust, D. Tissue-Resident Memory T Cells. Immunity 2014, 41, 886-897. [CrossRef]

10. Mueller, S.N.; Mackay, L.K. Tissue-resident memory T cells: Local specialists in immune defence. Nat. Rev. Immunol. 2016, 16, 79-89. [CrossRef]

11. Carbone, F.R. Tissue-Resident Memory T Cells and Fixed Immune Surveillance in Nonlymphoid Organs. J. Immunol. 2015, 195, 17-22. [CrossRef]

12. Jiang, X.; Clark, R.A.; Liu, L.; Wagers, A.J.; Fuhlbrigge, R.C.; Kupper, T.S. Skin infection generates non-migratory memory CD8 ${ }^{+}$ TRM cells providing global skin immunity. Nature 2012, 483, 227-231. [CrossRef] [PubMed]

13. Behr, F.M.; Parga-Vidal, L.; Kragten, N.A.M.; van Dam, T.J.P.; Wesselink, T.H.; Sheridan, B.S.; Arens, R.; van Lier, R.A.W.; Stark, R.; van Gisbergen, K.P.J.M. Tissue-resident memory CD8 ${ }^{+} \mathrm{T}$ cells shape local and systemic secondary T cell responses. Nat. Immunol. 2020, 21, 1070-1081. [CrossRef] [PubMed]

14. Fonseca, R.; Beura, L.K.; Quarnstrom, C.F.; Ghoneim, H.E.; Fan, Y.; Zebley, C.C.; Scott, M.C.; Fares-Frederickson, N.J.; Wijeyesinghe, S.; Thompson, E.A.; et al. Developmental plasticity allows outside-in immune responses by resident memory T cells. Nat. Immunol. 2020, 21, 412-421. [CrossRef] [PubMed]

15. Masopust, D.; Vezys, V.; Wherry, E.J.; Barber, D.L.; Ahmed, R. Cutting Edge: Gut Microenvironment Promotes Differentiation of a Unique Memory CD8 T Cell Population. J. Immunol. 2006, 176, 2079-2083. [CrossRef] [PubMed]

16. Mackay, L.K.; Rahimpour, A.; Ma, J.Z.; Collins, N.; Stock, A.T.; Hafon, M.-L.; Vega-Ramos, J.; Lauzurica, P.; Mueller, S.N.; Stefanovic, T.; et al. The developmental pathway for $\mathrm{CD}_{103}{ }^{+} \mathrm{CD} 8^{+}$tissue-resident memory T cells of skin. Nat. Immunol. 2013, 14, 1294-1301. [CrossRef]

17. Gebhardt, T.; Whitney, P.G.; Zaid, A.; Mackay, L.K.; Brooks, A.G.; Heath, W.R.; Carbone, F.R.; Mueller, S.N. Different patterns of peripheral migration by memory $\mathrm{CD}^{+}$and $\mathrm{CD} 8^{+} \mathrm{T}$ cells. Nature 2011, 477, 216-219. [CrossRef]

18. Teijaro, J.R.; Turner, D.; Pham, Q.; Wherry, E.J.; Lefrançois, L.; Farber, D.L. Cutting Edge: Tissue-Retentive Lung Memory CD4 T Cells Mediate Optimal Protection to Respiratory Virus Infection. J. Immunol. 2011, 187, 5510-5514. [CrossRef]

19. Anderson, K.G.; Sung, H.; Skon, C.N.; Lefrancois, L.; Deisinger, A.; Vezys, V.; Masopust, D. Cutting Edge: Intravascular Staining Redefines Lung CD8 T Cell Responses. J. Immunol. 2012, 189, 2702-2706. [CrossRef]

20. Schenkel, J.M.; Fraser, K.A.; Vezys, V.; Masopust, D. Sensing and alarm function of resident memory CD8 ${ }^{+}$T cells. Nat. Immunol. 2013, 14, 509-513. [CrossRef]

21. Iijima, N.; Iwasaki, A. A local macrophage chemokine network sustains protective tissue-resident memory CD4 T cells. Science 2014, 346, 93-98. [CrossRef] [PubMed]

22. Sasson, S.C.; Gordon, C.L.; Christo, S.N.; Klenerman, P.; Mackay, L.K. Local heroes or villains: Tissue-resident memory T cells in human health and disease. Cell. Mol. Immunol. 2020, 17, 113-122. [CrossRef] [PubMed] 
23. Clark, R.A.; Chong, B.; Mirchandani, N.; Brinster, N.K.; Yamanaka, K.; Dowgiert, R.K.; Kupper, T.S. The Vast Majority of CLA+ T Cells Are Resident in Normal Skin. J. Immunol. 2006, 176, 4431-4439. [CrossRef]

24. Watanabe, R.; Gehad, A.; Yang, C.; Scott, L.L.; Teague, J.E.; Schlapbach, C.; Elco, C.P.; Huang, V.; Matos, T.R.; Kupper, T.S.; et al. Human skin is protected by four functionally and phenotypically discrete populations of resident and recirculating memory $\mathrm{T}$ cells. Sci. Transl. Med. 2015, 7, 279ra39. [CrossRef]

25. Gaide, O.; Emerson, R.O.; Jiang, X.; Gulati, N.; Nizza, S.; Desmarais, C.; Robins, H.; Krueger, J.G.; Clark, R.A.; Kupper, T.S. Common clonal origin of central and resident memory T cells following skin immunization. Nat. Med. 2015, 21, 647-653. [CrossRef] [PubMed]

26. Mizukawa, Y.; Yamazaki, Y.; Teraki, Y.; Hayakawa, J.; Hayakawa, K.; Nuriya, H.; Kohara, M.; Shiohara, T. Direct Evidence for Interferon- $\gamma$ Production by Effector-Memory-Type Intraepidermal T Cells Residing at an Effector Site of Immunopathology in Fixed Drug Eruption. Am. J. Pathol. 2002, 161, 1337-1347. [CrossRef]

27. Amsen, D.; van Gisbergen, K.P.J.M.; Hombrink, P.; van Lier, R.A.W. Tissue-resident memory T cells at the center of immunity to solid tumors. Nat. Immunol. 2018, 19, 538-546. [CrossRef]

28. Edwards, J.; Wilmott, J.S.; Madore, J.; Gide, T.N.; Quek, C.; Tasker, A.; Ferguson, A.; Chen, J.; Hewavisenti, R.; Hersey, P.; et al. $\mathrm{CD} 103^{+}$Tumor-Resident CD8 ${ }^{+} \mathrm{T}$ Cells Are Associated with Improved Survival in Immunotherapy-Naïve Melanoma Patients and Expand Significantly During Anti-PD-1 Treatment. Clin. Cancer Res. 2018, 24, 3036-3045. [CrossRef]

29. Vieyra-Garcia, P.; Crouch, J.D.; O’Malley, J.T.; Seger, E.W.; Yang, C.H.; Teague, J.E.; Vromans, A.M.; Gehad, A.; Win, T.S.; Yu, Z.; et al. Benign T cells drive clinical skin inflammation in cutaneous T cell lymphoma. JCI Insight 2019, 4, e124233. [CrossRef]

30. Cheuk, S.; Schlums, H.; Gallais Sérézal, I.; Martini, E.; Chiang, S.C.; Marquardt, N.; Gibbs, A.; Detlofsson, E.; Introini, A.; Forkel, M.; et al. CD49a Expression Defines Tissue-Resident CD8 ${ }^{+}$T Cells Poised for Cytotoxic Function in Human Skin. Immunity 2017, 46, 287-300. [CrossRef]

31. Xing, L.; Dai, Z.; Jabbari, A.; Cerise, J.E.; Higgins, C.A.; Gong, W.; de Jong, A.; Harel, S.; DeStefano, G.M.; Rothman, L.; et al. Alopecia areata is driven by cytotoxic T lymphocytes and is reversed by JAK inhibition. Nat. Med. 2014, 20, 1043-1049. [CrossRef]

32. Zaid, A.; Mackay, L.K.; Rahimpour, A.; Braun, A.; Veldhoen, M.; Carbone, F.R.; Manton, J.H.; Heath, W.R.; Mueller, S.N. Persistence of skin-resident memory T cells within an epidermal niche. Proc. Natl. Acad. Sci. USA 2014, 111, 5307-5312. [CrossRef] [PubMed]

33. Steinert, E.M.; Schenkel, J.M.; Fraser, K.A.; Beura, L.K.; Manlove, L.S.; Igyártó, B.Z.; Southern, P.J.; Masopust, D. Quantifying Memory CD8 T Cells Reveals Regionalization of Immunosurveillance. Cell 2015, 161, 737-749. [CrossRef] [PubMed]

34. Cepek, K.L.; Shaw, S.K.; Parker, C.M.; Russell, G.J.; Morrow, J.S.; Rimm, D.L.; Brenner, M.B. Adhesion between epithelial cells and T lymphocytes mediated by E-cadherin and the $\alpha E \beta 7$ integrin. Nature 1994, 372, 190-193. [CrossRef]

35. Mackay, L.K.; Braun, A.; Macleod, B.L.; Collins, N.; Tebartz, C.; Bedoui, S.; Carbone, F.R.; Gebhardt, T. Cutting Edge: CD69 Interference with Sphingosine-1-Phosphate Receptor Function Regulates Peripheral T Cell Retention. J. Immunol. 2015, 194, 2059-2063. [CrossRef]

36. Cibrian, D.; Saiz, M.L.; De La Fuente, H.; Sánchez-Díaz, R.; Moreno-Gonzalo, O.; Jorge, I.; Ferrarini, A.; Vázquez, J.; Punzón, C.; Fresno, M.; et al. CD69 controls the uptake of L-tryptophan through LAT1-CD98 and AhR-dependent secretion of IL-22 in psoriasis. Nat. Immunol. 2016, 17, 985-996. [CrossRef] [PubMed]

37. Bergsbaken, T.; Bevan, M.J. Proinflammatory microenvironments within the intestine regulate the differentiation of tissue-resident $\mathrm{CD}^{+} \mathrm{T}$ cells responding to infection. Nat. Immunol. 2015, 16, 406-414. [CrossRef]

38. Schenkel, J.M.; Fraser, K.A.; Masopust, D. Cutting Edge: Resident Memory CD8 T Cells Occupy Frontline Niches in Secondary Lymphoid Organs. J. Immunol. 2014, 192, 2961-2964. [CrossRef] [PubMed]

39. Wakim, L.M.; Woodward-Davis, A.; Bevan, M.J. Memory T cells persisting within the brain after local infection show functional adaptations to their tissue of residence. Proc. Natl. Acad. Sci. USA 2010, 107, 17872-17879. [CrossRef]

40. Sowell, R.T.; Rogozinska, M.; Nelson, C.E.; Vezys, V.; Marzo, A.L. Cutting Edge: Generation of Effector Cells That Localize to Mucosal Tissues and Form Resident Memory CD8 T Cells Is Controlled by mTOR. J. Immunol. 2014, 193, 2067-2071. [CrossRef]

41. Hombrink, P.; Helbig, C.; Backer, R.A.; Piet, B.; Oja, A.E.; Stark, R.; Brasser, G.; Jongejan, A.; Jonkers, R.E.; Nota, B.; et al. Programs for the persistence, vigilance and control of human $\mathrm{CD}^{8+}$ lung-resident memory T cells. Nat. Immunol. 2016, 17, 1467-1478. [CrossRef]

42. Pan, Y.; Tian, T.; Park, C.O.; Lofftus, S.Y.; Mei, S.; Liu, X.; Luo, C.; O’Malley, J.T.; Gehad, A.; Teague, J.E.; et al. Survival of tissue-resident memory T cells requires exogenous lipid uptake and metabolism. Nature 2017, 543, 252-256. [CrossRef] [PubMed]

43. Liikanen, I.; Lauhan, C.; Quon, S.; Omilusik, K.; Phan, A.T.; Bartrolí, L.B.; Ferry, A.; Goulding, J.; Chen, J.; Scott-Browne, J.P.; et al. Hypoxia-inducible factor activity promotes antitumor effector function and tissue residency by CD8 ${ }^{+} \mathrm{T}$ cells. J. Clin. Investig. 2021, 131, e143729. [CrossRef]

44. Mackay, L.K.; Wynne-Jones, E.; Freestone, D.; Pellicci, D.G.; Mielke, L.A.; Newman, D.M.; Braun, A.; Masson, F.; Kallies, A.; Belz, G.T.; et al. T-box Transcription Factors Combine with the Cytokines TGF- $\beta$ and IL-15 to Control Tissue-Resident Memory T Cell Fate. Immunity 2015, 43, 1101-1111. [CrossRef] [PubMed]

45. Mackay, L.K.; Minnich, M.; Kragten, N.A.M.; Liao, Y.; Nota, B.; Seillet, C.; Zaid, A.; Man, K.; Preston, S.; Freestone, D.; et al. Hobit and Blimp1 instruct a universal transcriptional program of tissue residency in lymphocytes. Science 2016, 352, 459-463. [CrossRef] [PubMed] 
46. Strobl, J.; Pandey, R.V.; Krausgruber, T.; Bayer, N.; Kleissl, L.; Reininger, B.; Vieyra-Garcia, P.; Wolf, P.; Jentus, M.-M.; Mitterbauer, M.; et al. Long-term skin-resident memory T cells proliferate in situ and are involved in human graft-versus-host disease (GVHD). Sci. Transl. Med. 2020, 12, eabb7028. [CrossRef] [PubMed]

47. Milner, J.J.; Toma, C.; Yu, B.; Zhang, K.; Omilusik, K.; Phan, A.T.; Wang, D.; Getzler, A.J.; Nguyen, T.; Crotty, S.; et al. Runx3 programs $\mathrm{CD}^{+} \mathrm{T}$ cell residency in non-lymphoid tissues and tumours. Nature 2017, 552, 253-257. [CrossRef]

48. Campbell, J.J.; Haraldsen, G.; Pan, J.; Rottman, J.; Qin, S.; Ponath, P.; Andrew, D.P.; Warnke, R.; Ruffing, N.; Kassam, N.; et al. The chemokine receptor CCR4 in vascular recognition by cutaneous but not intestinal memory T cells. Nature 1999, 400, 776-780. [CrossRef]

49. Homey, B.; Alenius, H.; Müller, A.; Soto, H.; Bowman, E.P.; Yuan, W.; McEvoy, L.; Lauerma, A.I.; Assmann, T.; Bünemann, E.; et al. CCL27-CCR10 interactions regulate T cell-mediated skin inflammation. Nat. Med. 2002, 8, 157-165. [CrossRef]

50. McCully, M.L.; Ladell, K.; Hakobyan, S.; Mansel, R.E.; Price, D.A.; Moser, B. Epidermis instructs skin homing receptor expression in human T cells. Blood 2012, 120, 4591-4598. [CrossRef]

51. Xia, M.; Hu, S.; Fu, Y.; Jin, W.; Yi, Q.; Matsui, Y.; Yang, J.; McDowell, M.A.; Sarkar, S.; Kalia, V.; et al. CCR10 regulates balanced maintenance and function of resident regulatory and effector T cells to promote immune homeostasis in the skin. J. Allergy Clin. Immunol. 2014, 134, 634-644. [CrossRef] [PubMed]

52. Zaid, A.; Hor, J.L.; Christo, S.N.; Groom, J.R.; Heath, W.R.; Mackay, L.K.; Mueller, S.N. Chemokine Receptor-Dependent Control of Skin Tissue-Resident Memory T Cell Formation. J. Immunol. 2017, 199, 2451-2459. [CrossRef]

53. Kok, L.; Dijkgraaf, F.E.; Urbanus, J.; Bresser, K.; Vredevoogd, D.W.; Cardoso, R.F.; Perié, L.; Beltman, J.B.; Schumacher, T.N. A committed tissue-resident memory $\mathrm{T}$ cell precursor within the circulating CD8 ${ }^{+}$effector T cell pool. J. Exp. Med. 2020, 217, e20191711. [CrossRef]

54. Kurd, N.S.; He, Z.; Louis, T.L.; Milner, J.J.; Omilusik, K.D.; Jin, W.; Tsai, M.S.; Widjaja, C.E.; Kanbar, J.N.; Olvera, J.G.; et al. Early precursors and molecular determinants of tissue-resident memory $\mathrm{CD} 8^{+} \mathrm{T}$ lymphocytes revealed by single-cell RNA sequencing. Sci. Immunol. 2020, 5, eaaz6894. [CrossRef]

55. Sathaliyawala, T.; Kubota, M.; Yudanin, N.; Turner, D.; Camp, P.; Thome, J.J.C.; Bickham, K.L.; Lerner, H.; Goldstein, M.; Sykes, M.; et al. Distribution and Compartmentalization of Human Circulating and Tissue-Resident Memory T Cell Subsets. Immunity 2013, 38, 187-197. [CrossRef]

56. Kumar, B.V.; Ma, W.; Miron, M.; Granot, T.; Guyer, R.S.; Carpenter, D.J.; Senda, T.; Sun, X.; Ho, S.-H.; Lerner, H.; et al. Human Tissue-Resident Memory T Cells Are Defined by Core Transcriptional and Functional Signatures in Lymphoid and Mucosal Sites. Cell Rep. 2017, 20, 2921-2934. [CrossRef]

57. Wong, M.T.; Ong, D.E.H.; Lim, F.S.H.; Teng, K.W.W.; McGovern, N.; Narayanan, S.; Ho, W.Q.; Cerny, D.; Tan, H.K.K.; Anicete, R.; et al. A High-Dimensional Atlas of Human T Cell Diversity Reveals Tissue-Specific Trafficking and Cytokine Signatures. Immunity 2016, 45, 442-456. [CrossRef]

58. Clark, R.A.; Watanabe, R.; Teague, J.E.; Schlapbach, C.; Tawa, M.C.; Adams, N.; Dorosario, A.A.; Chaney, K.S.; Cutler, C.S.; LeBoeuf, N.R.; et al. Skin Effector Memory T Cells Do Not Recirculate and Provide Immune Protection in Alemtuzumab-Treated CTCL Patients. Sci. Transl. Med. 2012, 4, 117ra7. [CrossRef]

59. Koguchi-Yoshioka, H.; Hoffer, E.; Cheuk, S.; Matsumura, Y.; Vo, S.; Kjellman, P.; Grema, L.; Ishitsuka, Y.; Nakamura, Y.; Okiyama, N.; et al. Skin T cells maintain their diversity and functionality in the elderly. Commun. Biol. 2021, 4, 13. [CrossRef]

60. Park, C.O.; Fu, X.; Jiang, X.; Pan, Y.; Teague, J.E.; Collins, N.; Tian, T.; O’Malley, J.T.; Emerson, R.O.; Kim, J.H.; et al. Staged development of long-lived T-cell receptor $\alpha \beta$ TH17 resident memory T-cell population to Candida albicans after skin infection. J. Allergy Clin. Immunol. 2018, 142, 647-662. [CrossRef] [PubMed]

61. Collins, N.; Jiang, X.; Zaid, A.; Macleod, B.L.; Li, J.; Park, C.O.; Haque, A.; Bedoui, S.; Heath, W.R.; Mueller, S.N.; et al. Skin CD4 memory $\mathrm{T}$ cells exhibit combined cluster-mediated retention and equilibration with the circulation. Nat. Commun. 2016, 7, 11514. [CrossRef] [PubMed]

62. Cheuk, S.; Wikén, M.; Blomqvist, L.; Nylén, S.; Talme, T.; Ståhle, M.; Eidsmo, L. Epidermal Th22 and Tc17 Cells Form a Localized Disease Memory in Clinically Healed Psoriasis. J. Immunol. 2014, 192, 3111-3120. [CrossRef]

63. Adachi, T.; Kobayashi, T.; Sugihara, E.; Yamada, T.; Ikuta, K.; Pittaluga, S.; Saya, H.; Amagai, M.; Nagao, K. Hair follicle-derived IL-7 and IL-15 mediate skin-resident memory T cell homeostasis and lymphoma. Nat. Med. 2015, 21, 1272-1279. [CrossRef] [PubMed]

64. Tokura, Y.; Phadungsaksawasdi, P.; Kurihara, K.; Fujiyama, T.; Honda, T. Pathophysiology of Skin Resident Memory T Cells. Front. Immunol. 2021, 11, 3789. [CrossRef] [PubMed]

65. Adams, E.J.; Gu, S.; Luoma, A.M. Human gamma delta T cells: Evolution and ligand recognition. Cell. Immunol. 2015, 296, 31-40. [CrossRef] [PubMed]

66. Reitermaier, R.; Krausgruber, T.; Fortelny, N.; Ayub, T.; Vieyra-Garcia, P.A.; Kienzl, P.; Wolf, P.; Scharrer, A.; Fiala, C.; Kölz, M.; et al. $\alpha \beta \gamma \delta$ T cells play a vital role in fetal human skin development and immunity. J. Exp. Med. 2021, 218, e20201189. [CrossRef]

67. Koguchi-Yoshioka, H.; Watanabe, R.; Matsumura, Y.; Okiyama, N.; Ishitsuka, Y.; Nakamura, Y.; Fujisawa, Y.; Fujimoto, M. The Possible Linkage of Granzyme B-Producing Skin T Cells with the Disease Prognosis of Alopecia Areata. J. Investig. Dermatol. 2021, 141, 427-429. [CrossRef] [PubMed]

68. Kim, S.; Park, C.; Shin, J.; Noh, J.; Kim, H.; Kim, J.; Lee, H.; Lee, J.; Kupper, T.S.; Lee, K. Multicytokine-producing tissue resident memory (TRM) cells in atopic dermatitis patient. J. Investig. Dermatol. 2016, 136, S9. [CrossRef] 
69. Boniface, K.; Jacquemin, C.; Darrigade, A.-S.; Dessarthe, B.; Martins, C.; Boukhedouni, N.; Vernisse, C.; Grasseau, A.; Thiolat, D.; Rambert, J.; et al. Vitiligo Skin Is Imprinted with Resident Memory CD8 T Cells Expressing CXCR3. J. Investig. Dermatol. 2018, 138, 355-364. [CrossRef]

70. Han, J.; Zhao, Y.; Shirai, K.; Molodtsov, A.; Kolling, F.W.; Fisher, J.L.; Zhang, P.; Yan, S.; Searles, T.G.; Bader, J.M.; et al. Resident and circulating memory $\mathrm{T}$ cells persist for years in melanoma patients with durable responses to immunotherapy. Nat. Cancer 2021, 2, 300-311. [CrossRef]

71. Zeng, J.; Luo, S.; Huang, Y.; Lu, Q. Critical role of environmental factors in the pathogenesis of psoriasis. J. Dermatol. 2017, 44, 863-872. [CrossRef]

72. Li, Q.; Chandran, V.; Tsoi, L.; O’Rielly, D.; Nair, R.P.; Gladman, D.; Elder, J.T.; Rahman, P. Quantifying Differences in Heritability among Psoriatic Arthritis (PsA), Cutaneous Psoriasis (PsC) and Psoriasis vulgaris (PsV). Sci. Rep. 2020, 10, 4925. [CrossRef]

73. Lande, R.; Botti, E.; Jandus, C.; Dojcinovic, D.; Fanelli, G.; Conrad, C.; Chamilos, G.; Feldmeyer, L.; Marinari, B.; Chon, S.; et al. The antimicrobial peptide LL37 is a T-cell autoantigen in psoriasis. Nat. Commun. 2014, 5, 5621. [CrossRef]

74. Bhushan, M.; Bleiker, T.O.; Ballsdon, A.E.; Allen, M.H.; Sopwith, M.; Robinson, M.K.; Clarke, C.; Weller, R.P.J.B.; Graham-Brown, R.A.C.; Keefe, M.; et al. Anti-E-selectin is ineffective in the treatment of psoriasis: A randomized trial. Br. J. Dermatol. 2002, 146, 824-831. [CrossRef]

75. Lebwohl, M.; Tyring, S.K.; Hamilton, T.K.; Toth, D.; Glazer, S.; Tawfik, N.H.; Walicke, P.; Dummer, W.; Wang, X.; Garovoy, M.R.; et al. A Novel Targeted T-Cell Modulator, Efalizumab, for Plaque Psoriasis. N. Engl. J. Med. 2003, 349, 2004-2013. [CrossRef]

76. Conrad, C.; Boyman, O.; Tonel, G.; Tun-Kyi, A.; Laggner, U.; de Fougerolles, A.; Kotelianski, V.; Gardner, H.; Nestle, F.O. $\alpha 1 \beta 1$ integrin is crucial for accumulation of epidermal T cells and the development of psoriasis. Nat. Med. 2007, 13, 836-842. [CrossRef] [PubMed]

77. Gallais Sérézal, I.; Hoffer, E.; Ignatov, B.; Martini, E.; Zitti, B.; Ehrström, M.; Eidsmo, L. A skewed pool of resident T cells triggers psoriasis-associated tissue responses in never-lesional skin from patients with psoriasis. J. Allergy Clin. Immunol. 2019, 143, 1444-1454. [CrossRef] [PubMed]

78. Nograles, K.E.; Zaba, L.C.; Guttman-Yassky, E.; Fuentes-Duculan, J.; Suárez-Fariñas, M.; Cardinale, I.; Khatcherian, A.; Gonzalez, J.; Pierson, K.C.; White, T.R.; et al. Th17 cytokines interleukin (IL)-17 and IL-22 modulate distinct inflammatory and keratinocyteresponse pathways. Br. J. Dermatol. 2008, 159, 1092-1102. [CrossRef] [PubMed]

79. Martini, E.; Wikén, M.; Cheuk, S.; Gallais Sérézal, I.; Baharom, F.; Ståhle, M.; Smed-Sörensen, A.; Eidsmo, L. Dynamic Changes in Resident and Infiltrating Epidermal Dendritic Cells in Active and Resolved Psoriasis. J. Investig. Dermatol. 2017, 137, 865-873. [CrossRef]

80. Matos, T.R.; O’Malley, J.T.; Lowry, E.L.; Hamm, D.; Kirsch, I.R.; Robins, H.S.; Kupper, T.S.; Krueger, J.G.; Clark, R.A. Clinically resolved psoriatic lesions contain psoriasis-specific IL-17-producing $\alpha \beta$ T cell clones. J. Clin. Investig. 2017, 127, 4031-4041. [CrossRef]

81. Lande, R.; Gregorio, J.; Facchinetti, V.; Chatterjee, B.; Wang, Y.-H.; Homey, B.; Cao, W.; Wang, Y.-H.; Su, B.; Nestle, F.O.; et al. Plasmacytoid dendritic cells sense self-DNA coupled with antimicrobial peptide. Nature 2007, 449, 564-569. [CrossRef] [PubMed]

82. Zaba, L.C.; Krueger, J.G.; Lowes, M.A. Resident and “Inflammatory" Dendritic Cells in Human Skin. J. Investig. Dermatol. 2009, 129, 302-308. [CrossRef]

83. Arakawa, A.; Siewert, K.; Stöhr, J.; Besgen, P.; Kim, S.-M.; Rühl, G.; Nickel, J.; Vollmer, S.; Thomas, P.; Krebs, S.; et al. Melanocyte antigen triggers autoimmunity in human psoriasis. J. Exp. Med. 2015, 212, 2203-2212. [CrossRef]

84. Cheung, K.L.; Jarrett, R.; Subramaniam, S.; Salimi, M.; Gutowska-Owsiak, D.; Chen, Y.-L.; Hardman, C.; Xue, L.; Cerundolo, V.; $\mathrm{Ogg}$, G. Psoriatic T cells recognize neolipid antigens generated by mast cell phospholipase delivered by exosomes and presented by CD1a. J. Exp. Med. 2016, 213, 2399-2412. [CrossRef]

85. Jin, L.; Wang, G. Keratin 17: A Critical Player in the Pathogenesis of Psoriasis. Med. Res. Rev. 2014, 34, 438-454. [CrossRef]

86. Johnston, A.; Gudjonsson, J.E.; Sigmundsdottir, H.; Love, T.J.; Valdimarsson, H. Peripheral blood T cell responses to keratin peptides that share sequences with streptococcal $\mathrm{M}$ proteins are largely restricted to skin-homing CD8 ${ }^{+} \mathrm{T}$ cells. Clin. Exp. Immunol. 2004, 138, 83-93. [CrossRef]

87. Kurihara, K.; Fujiyama, T.; Phadungsaksawasdi, P.; Ito, T.; Tokura, Y. Significance of IL-17A-producing CD8 ${ }^{+} \mathrm{CD} 103^{+}$skin resident memory $\mathrm{T}$ cells in psoriasis lesion and their possible relationship to clinical course. J. Dermatol. Sci. 2019, 95, 21-27. [CrossRef] [PubMed]

88. Vo, S.; Watanabe, R.; Koguchi-Yoshioka, H.; Matsumura, Y.; Ishitsuka, Y.; Nakamura, Y.; Okiyama, N.; Fujisawa, Y.; Fujimoto, M. CD8 resident memory T cells with interleukin 17A-producing potential are accumulated in disease-naïve nonlesional sites of psoriasis possibly in correlation with disease duration. Br. J. Dermatol. 2019, 181, 410-412. [CrossRef]

89. Fenix, K.; Wijesundara, D.K.; Cowin, A.J.; Grubor-Bauk, B.; Kopecki, Z. Immunological memory in imiquimod-induced murine model of psoriasiform dermatitis. Int. J. Mol. Sci. 2020, 21, 7228. [CrossRef] [PubMed]

90. Di Meglio, P.; Villanova, F.; Navarini, A.A.; Mylonas, A.; Tosi, I.; Nestle, F.O.; Conrad, C. Targeting CD8 ${ }^{+}$T cells prevents psoriasis development. J. Allergy Clin. Immunol. 2016, 138, 274-276.e6. [CrossRef] [PubMed]

91. Fujiyama, T.; Umayahara, T.; Kurihara, K.; Shimauchi, T.; Ito, T.; Aoshima, M.; Otobe, E.; Hashizume, H.; Yagi, H.; Tokura, Y. Skin infiltration of pathogenic migratory and resident $\mathrm{T}$ cells is decreased by Secukinumab treatment in psoriasis. J. Investig. Dermatol. 2020, 140, 2073-2076. [CrossRef] 
92. Mashiko, S.; Edelmayer, R.M.; Bi, Y.; Olson, L.M.; Wetter, J.B.; Wang, J.; Maari, C.; Saint-Cyr Proulx, E.; Kaimal, V.; Li, X.; et al. Persistence of Inflammatory Phenotype in Residual Psoriatic Plaques in Patients on Effective Biologic Therapy. J. Investig. Dermatol. 2020, 140, 1015-1025.e4. [CrossRef]

93. Gallais Sérézal, I.; Classon, C.; Cheuk, S.; Barrientos-Somarribas, M.; Wadman, E.; Martini, E.; Chang, D.; Xu Landén, N.; Ehrström, M.; Nylén, S.; et al. Resident T Cells in Resolved Psoriasis Steer Tissue Responses that Stratify Clinical Outcome. J. Investig. Dermatol. 2018, 138, 1754-1763. [CrossRef]

94. Papp, K.A.; Reich, K.; Paul, C.; Blauvelt, A.; Baran, W.; Bolduc, C.; Toth, D.; Langley, R.G.; Cather, J.; Gottlieb, A.B.; et al. A prospective phase III, randomized, double-blind, placebo-controlled study of brodalumab in patients with moderate-to-severe plaque psoriasis. Br. J. Dermatol. 2016, 175, 273-286. [CrossRef]

95. Mehta, H.; Mashiko, S.; Angsana, J.; Rubio, M.; Hsieh, Y.-C.M.; Maari, C.; Reich, K.; Blauvelt, A.; Bissonnette, R.; Muñoz-Elías, E.J.; et al. Differential Changes in Inflammatory Mononuclear Phagocyte and T-Cell Profiles within Psoriatic Skin during Treatment with Guselkumab vs. Secukinumab. J. Investig. Dermatol. 2021, 141, 1707-1718.e9. [CrossRef] [PubMed]

96. Søyland, E.; Heier, I.; Rodríguez-Gallego, C.; Mollnes, T.E.; Johansen, F.-E.; Holven, K.B.; Halvorsen, B.; Aukrust, P.; Jahnsen, F.L.; de la Rosa Carrillo, D.; et al. Sun exposure induces rapid immunological changes in skin and peripheral blood in patients with psoriasis. Br. J. Dermatol. 2011, 164, 344-355. [CrossRef]

97. Dyring-Andersen, B.; Bonefeld, C.M.; Bzorek, M.; Løvendorf, M.B.; Lauritsen, J.P.H.; Skov, L.; Geisler, C. The Vitamin D Analogue Calcipotriol Reduces the Frequency of CD8 ${ }^{+} \mathrm{IL}-17^{+} \mathrm{T}$ Cells in Psoriasis Lesions. Scand. J. Immunol. 2015, 82, 84-91. [CrossRef]

98. Fujiyama, T.; Ito, T.; Umayahara, T.; Ikeya, S.; Tatsuno, K.; Funakoshi, A.; Hashizume, H.; Tokura, Y. Topical application of a vitamin D3 analogue and corticosteroid to psoriasis plaques decreases skin infiltration of TH17 cells and their ex vivo expansion. J. Allergy Clin. Immunol. 2016, 138, 517-528. [CrossRef] [PubMed]

99. Gottlieb, S.L.; Hayes, E.; Gilleaudeau, P.; Cardinale, I.; Gottlieb, A.B.; Krueger, J.G. Cellular actions of etretinate in psoriasis: Enhanced epidermal differentiation and reduced cell-mediated inflammation are unexpected outcomes. J. Cutan. Pathol. 1996, 23, 404-418. [CrossRef]

100. Xiao, S.; Jin, H.; Korn, T.; Liu, S.M.; Oukka, M.; Lim, B.; Kuchroo, V.K. Retinoic Acid Increases Foxp3+ Regulatory T Cells and Inhibits Development of Th17 Cells by Enhancing TGF- $\beta$-Driven Smad3 Signaling and Inhibiting IL-6 and IL-23 Receptor Expression. J. Immunol. 2008, 181, 2277-2284. [CrossRef] [PubMed]

101. Gottlieb, A.B.; Matheson, R.T.; Menter, A.; Leonardi, C.L.; Day, R.M.; Hu, C.; Schafer, P.H. Efficacy, tolerability, and pharmacodynamics of apremilast in recalcitrant plaque psoriasis: A phase II open-label study. J. Drugs Dermatol. 2013, 12, 888-897. [PubMed]

102. Robbins, K.; Bissonnette, R.; Maeda-Chubachi, T.; Ye, L.; Peppers, J.; Gallagher, K.; Kraus, J.E. Phase 2, randomized dose-finding study of tapinarof (GSK2894512 cream) for the treatment of plaque psoriasis. J. Am. Acad. Dermatol. 2019, 80, 714-721. [CrossRef] [PubMed]

103. Kobayashi, T.; Ricardo-Gonzalez, R.R.; Moro, K. Skin-Resident Innate Lymphoid Cells-Cutaneous Innate Guardians and Regulators. Trends Immunol. 2020, 41, 100-112. [CrossRef] [PubMed]

104. Weisel, N.M.; Weisel, F.J.; Farber, D.L.; Borghesi, L.A.; Shen, Y.; Ma, W.; Luning Prak, E.T.; Shlomchik, M.J. Comprehensive analyses of B-cell compartments across the human body reveal novel subsets and a gut-resident memory phenotype. Blood 2020, 136, 2774-2785. [CrossRef] [PubMed] 